\title{
Contribution of gut microbial lysine to liver and milk amino acids in lactating does
}

\author{
Leticia Abecia $^{1,2}$, Joaquím Balcells ${ }^{1 *}$, Manuel Fondevila ${ }^{1}$, Alvaro Belenguer ${ }^{1,2}$, Grietje Holtrop ${ }^{3}$ \\ and Gerald E. Lobley ${ }^{2}$ \\ ${ }^{1}$ Departamento de Producción Animal y Ciencia de los Alimentos, Universidad de Zaragoza, 50013, Spain \\ ${ }^{2}$ Rowett Research Institute, Bucksburn, Aberdeen AB21 9SB, UK \\ ${ }^{3}$ Biomathematics and Statistics Scotland, Bucksburn, Aberdeen AB21 9SB, UK
}

(Received 18 July 2007 - Revised 28 January 2008 - Accepted 29 January 2008 - First published online 12 March 2008)

The contribution of microbial amino acids through caecotrophy to tissue protein metabolism was investigated in lactating does. Attempts were made to vary microbial supply through a dietary antibiotic, $\mathrm{Zn}$ bacitracin, and to vary tissue demand through manipulation of litter size. Three groups of eight New Zealand does were fed different experimental diets from day 28 of pregnancy to day 26 of lactation. The control group received the basal diet formulated to meet requirements with grass hay, wheat, soyabean meal and barley grain. The second (no antibiotic) group and the third (bacitracin; BAC) group ingested the basal diet supplemented with ammonium sulfate $(5 \mathrm{~g} / \mathrm{kg}$ ), initially unlabelled (day 1 to day 8$)$ then labelled with ${ }^{15} \mathrm{~N}$ (day 9 to day 30), while the BAC diet was also supplemented throughout with antibiotic ( $\mathrm{Zn}$ bacitracin; $100 \mathrm{mg} / \mathrm{kg}$ ). From just after birth each group of does was subdivided into two groups, each of four females, with the litter size either five (LS5) or nine (LS9) pups. The ${ }^{15} \mathrm{~N}$ enrichment in liver, milk and caecal bacteria amino acids was determined by GC-combustion-isotope ratio MS. All amino acids in bacterial protein were enriched with the $\left({ }^{15} \mathrm{NH}_{4}\right)_{2} \mathrm{SO}_{4}$ treatment, with lysine ${ }^{15} \mathrm{~N}$ enrichment significantly greater in caecal bacteria $(0 \cdot 23$ (SE 0.0063$)$ atom \% excess (ape)) than in liver (0.04 (SE 0.0004) ape) or milk protein (0.05 (SE 0.0018) ape), confirming the double origin (bacterial and dietary) of tissue lysine. The contribution of microbes to tissue lysine was 0.23 (SE 0.006) when milk protein was used as reference.

Caecotrophy: Rabbit does: Microbial lysine

Although the contribution of microbially derived essential amino acids to absorptive supply has been well documented in ruminants, fewer data are available for non-ruminants. In pigs, recent reports suggest that $10 \%$ of lysine requirements are derived from intestinal bacteria ${ }^{(1)}$. In rabbits, caecotrophy is a crucial physiological process that provides a source of high-quality protein to the animal by recycling microbial biomass synthesised in the caecum. Therefore, protein nutrition in rabbits and others lagomorphs is impacted by factors that alter caecal fermentation ${ }^{(2,3)}$. Quantification of the microbial contribution to amino acid supply in rabbits is difficult. However, its importance is determined normally by fitting a neck collar to prevent soft faeces ingestion, but this methodology can affect both animal behaviour and digestive physiology ${ }^{(4-6)}$. An alternative technique, based on microbial $\left[{ }^{15} \mathrm{~N}\right] l y$ sine incorporation has been previously described in our group ${ }^{(3)}$ and, because this procedure does not alter animal behaviour, is particularly suitable for lactating does.

During lactation, nutrient requirements are raised markedly and rabbit does increase food intake, caecal fermentation and, reportedly, microbial-N recycling ${ }^{(7)}$. Data related to soft faeces intake in lactating does are scarce ${ }^{(7)}$ and similarity in the ingestive behaviour between lactating does and growing rabbits cannot be assumed because of the different physiological states.

Therefore, the aim of the present study was to determine the importance of microbial protein intake in lactating does and whether this is more critical during later lactation when milk output requirement is higher. The system was manipulated by altering litter size (five or nine pups) and by use of antibiotics to inhibit the caecal ecosystem and responses monitored.

\section{Material and methods}

Protocols and animal handling through the present experiment were approved by the Comité Etico del Servicio de Biomedicina y Biomateriales of the University of Zaragoza.

\section{Animals}

Twenty-four New Zealand White multiparous does with a mean initial body weight of 4.3 (SD 2.1 ) kg were used. Animals were randomised between three experimental groups and penned individually under $12 \mathrm{~h}$ light-dark conditions.

Abbreviations: AA, amino acid; ape, atom \% excess; BAC, bacitracin diet; LS5, litter size of five pups; LS9, litter size of nine pups; NAB, no antibiotic diet; ppm, parts per million; VFA, volatile fatty acid.

* Corresponding author: Dr Joaquím Balcells, fax +34 9767615 90, email balcells@unizar.es 


\section{Diets}

The basal diet was formulated $(\mathrm{g} / \mathrm{kg}$ ) with grass hay (400), wheat grain (200), soyabean meal (150), barley grain (130), sugarbeet pulp (100), sunflower-seed oil (5), ammonium sulfate (5) and a vitamin-mineral mix (10) with the following declared composition: $\mathrm{Co}\left(\mathrm{CoSO}_{4} \cdot 7 \mathrm{H}_{2} \mathrm{O}\right), 200$ parts per million $(\mathrm{ppm}) ; \mathrm{Cu}$ $\left(\mathrm{CuSO}_{4} .5 \mathrm{H}_{2} \mathrm{O}\right), 3000$ ppm; $\mathrm{Fe}\left(\mathrm{FeSO}_{4} \cdot \mathrm{H}_{2} \mathrm{O}\right), 20000$ ppm; $\mathrm{Mn}$ $\left(\mathrm{MnO}_{2}\right), 8000 \mathrm{ppm} ; \mathrm{Zn}(\mathrm{ZnO}), 30000 \mathrm{ppm} ; \mathrm{Se}\left(\mathrm{Na}_{2} \mathrm{SeO}_{3}\right)$, 30 ppm; I (KI), 500 ppm; vitamin A, $270 \mu$ kat (4 500000 IU)/ $\mathrm{kg}$; vitamin $\mathrm{D}_{3}, 33 \mu \mathrm{kat}(550000 \mathrm{IU}) / \mathrm{kg}$; vitamin $\mathrm{E}$, 1100 ppm; vitamin $B_{1}, 250$ ppm; vitamin $B_{2}, 1500$ ppm; vitamin $\mathrm{B}_{6}, 100 \mathrm{ppm}$; vitamin $\mathrm{B}_{12}, 6000 \mathrm{ppm}$; vitamin $\mathrm{K}, 500 \mathrm{ppm}$; Dpantothenate, $5000 \mathrm{ppm}$; niacin, $12500 \mathrm{ppm}$; choline chloride, $100000 \mathrm{ppm}$. Its chemical composition (per kg fresh matter) was $91.25 \mathrm{~g} \mathrm{DM}$, and (per $\mathrm{kg} \mathrm{DM}) 92.12 \mathrm{~g}$ organic matter, $19.06 \mathrm{~g}$ crude protein, $19.52 \mathrm{~g}$ acid-detergent fibre, $31.91 \mathrm{~g}$ neutral-detergent fibre, $4.81 \mathrm{~g}$ acid-detergent lignin and $2.67 \mathrm{~g}$ ether extract.

From $4 \mathrm{~d}$ before predicted parturition (day 1 of the experimental period) the groups were fed one of three experimental diets as follows: the control group received a basal diet. This group was used mainly to obtain the background amino acid enrichments. The second group (no antibiotic diet; NAB) received the basal diet plus ammonium sulfate $(5 \mathrm{~g} / \mathrm{kg})$, either unlabelled (day 1 to day 8) or labelled (10 atom \% $\left({ }^{15} \mathrm{NH}_{4}\right)_{2} \mathrm{SO}_{4}$; Cambridge Isotope Laboratories IL, Inc., Miamisburg, $\mathrm{OH}$, USA; day 9 to 30). The third group (bacitracin diet; BAC) received again the basal diet plus ammonium sulfate $(5 \mathrm{~g} / \mathrm{kg}$ ), either unlabelled (day 1 to day 8$)$ or labelled (day 9 to 30), but containing additionally an antibiotic, $\mathrm{Zn}$ bacitracin $(100 \mathrm{mg} / \mathrm{kg})$.

\section{Experimental design}

The experimental period lasted for $30 \mathrm{~d}$ after which does were killed. After parturition $(24 \mathrm{~h})$ the does were housed separately from their offspring and moved once daily to the cage containing the pups to allow suckling over an $8-10$ min period.

To modify lactation demand the litter size was modified by cross-fostering to either five (LS5) or nine (LS9) pups for each of four does within the group. DM intake, body weight and milk production of the does were studied across three periods post-parturition (L1, day 5 to day 12 of experiment; L2, day 13 to day 21; L3, day 22 to day 30). Milk yield was measured daily by weighing the does immediately before and after suckling.

On day 30, milk was obtained from the does by hand milking and then animals were killed by injection of sodium thiopental (Tiobarbital; Braun Medical SA, Barcelona, Spain). Liver samples were taken and immediately frozen in liquid $\mathrm{N}_{2}$. The caecum was quickly excised and weighed and the $\mathrm{pH}$ of the contents recorded. A sample $(1 \mathrm{~g})$ of caecal contents was immediately acidified $\left(0 \cdot 5 \mathrm{M}-\mathrm{H}_{3} \mathrm{PO}_{4}\right)$ and stored at $-20^{\circ} \mathrm{C}$ for subsequent volatile fatty acid (VFA) determination. The remaining caecal contents were weighed $(20-50 \mathrm{~g})$, diluted (1:10 by volume) in a methylcellulose (MC) solution $(9 \mathrm{~g} \mathrm{NaCl}$ and $1 \mathrm{~g} \mathrm{MC}$ per litre) and chilled at $4^{\circ} \mathrm{C}$ for $24 \mathrm{~h}$ to dislodge and isolate adherent bacteria as previously described ${ }^{(3)}$.

\section{Chemical analyses}

$\mathrm{DM}$ in the feeds was determined by drying at $60^{\circ} \mathrm{C}$ to constant weight. Organic matter was estimated by difference after ashing samples at $550^{\circ} \mathrm{C}$ for $8 \mathrm{~h}$. N was measured by the Kjeldahl method. Neutral- and acid-detergent fibre and acid-detergent lignin were determined according to Van Soest et al. ${ }^{(8)}$ after an amylase pre-treatment. Caecal VFA concentration was analysed by GLC, following the procedure described by Jouany ${ }^{(9)}$.

$\left[{ }^{15} \mathrm{~N}\right]$ amino acid (AA) enrichments in milk, microbial and liver tissue were measured by GC-combustion-isotope ratio MS, as described by Belenguer et al. ${ }^{(3)}$. AA concentrations were determined by HPLC using the Waters Pico-Tag method that involves pre-column derivatisation with phenylisothiocyanate $^{(10)}$.

For urine samples from the NAB group, urea $(250 \mu \mathrm{mol})$ was isolated from $\mathrm{NH}_{3}$ and amino acids by passage through $2 \mathrm{ml}$ cation exchange resin (DOWEX 50W X8 - 200 mesh, $\mathrm{H}+$ form; Sigma-Aldrich, Munich, Germany) as described by Sarraseca et al. ${ }^{(11)}$. Ammonia in the caecal contents was isolated as described by Jensen ${ }^{(12)}$. The ${ }^{15} \mathrm{~N}$ enrichments in bacteria, urea and ammonia were determined by an isotope ratio MS (IRMS) system (VG PRISM II, IRMS linked in series to a DUMAS-style N analyser EA 1108; Carlo Erba, Milan, Italy).

\section{Calculations}

Bacteria are considered to form the entire microbial population in the rabbit caecum and throughout the text bacterial and microbial are both used to refer to the caecal microbial population in the rabbit. The contribution of microbial lysine $\left(\mathrm{M}_{1 \mathrm{ys}}\right)$ to tissue lysine was estimated as described previously ${ }^{(3)}$ :

$$
\mathrm{M}_{\mathrm{lys}}=\frac{\mathrm{E}_{\text {Tris }}-\mathrm{E}_{\mathrm{TisC}}}{\mathrm{E}_{\mathrm{bac}}-\mathrm{E}_{\mathrm{bacC}}}
$$

where $\mathrm{E}_{\mathrm{Tis}}$ and $\mathrm{E}_{\mathrm{bac}}$ are $\left[{ }^{15} \mathrm{~N}\right]$ lysine enrichments (atom \%) in tissues and bacteria in animals fed the labelled diets while $\mathrm{E}_{\mathrm{TisC}}$ and $\mathrm{E}_{\mathrm{bacC}}$ are the corresponding enrichments from animals fed the unlabelled control diet.

Absorbed microbial lysine derived from caecotrophy $\left(\mathrm{M}_{\mathrm{lysA}}\right)$ was calculated as:

$$
\mathrm{M}_{\mathrm{lysA}}=\frac{\mathrm{M}_{\mathrm{lys}}(\mathrm{Cec}) \times \mathrm{D}_{\mathrm{lysA}}}{1-\mathrm{M}_{\mathrm{lys}}(\mathrm{Cec})-\mathrm{M}_{\mathrm{lys}}(\mathrm{Int})},
$$

where $\mathrm{M}_{\mathrm{lys}}(\mathrm{Cec})$ and $\mathrm{M}_{\mathrm{lys}}(\mathrm{Int})$ are the respective contributions of microbial lysine through the caecotrophy process and direct intestinal absorption to tissue lysine and $\mathrm{D}_{\text {lysa }}$ is the dietary supply of absorbed lysine, estimated from a true ileal digestibility of $0 \cdot 80^{(5)} \cdot \mathrm{M}_{\text {lys }}$ (Int) was assumed to be similar to the value estimated in growing rabbits $(3 \%)$, and $\mathrm{M}_{\mathrm{lys}}(\mathrm{Cec})$ was estimated by difference between $\mathrm{M}_{\mathrm{lys}}$ and $\mathrm{M}_{\mathrm{lys}}$ (Int).

Microbial intake (g DM/d) was calculated as follows:

$$
\text { Microbial intake }=\frac{\mathrm{M}_{\mathrm{lysA}} / \mathrm{TDig}}{\mathrm{BC}_{\mathrm{lys}}},
$$

where TDig is the true digestibility of microbial lysine $(0.897)^{(13)}$ and $\mathrm{BC}_{\mathrm{lys}}$ is the lysine concentration in caecal bacteria (g lysine/g DM). 


\section{Statistical analysis}

Data were analysed by ANOVA as a $3 \times 2$ factorial design, with diet, litter size and their interaction as main effects. Residual plots were inspected for normality and homogeneity of variance, and where necessary the data were log-transformed (enrichments). When measurements over time were taken (food intake, body-weight changes and milk yield), data were analysed by residual maximum likelihood (REML), with animal as a random effect and period, diet, litter size and their interactions as fixed effects. Various covariance matrix structures, including autoregressive and unstructured matrices, were investigated for the within-animal stratum. It was found that assuming identical correlations between the periods in combination with different variances for each of the three time periods (so-called uniform correlation with heterogeneous variance) gave the best fit, based on comparison of deviances using Akaike's information criterion.

For the AA enrichment data only, two diets were considered (BAC and NAB; Table 4) and they were analysed by ANOVA on log-transformed enrichments, for each amino acid individually. Animal was regarded as a random effect. Homogeneity of variances was investigated as follows. For the within-animal stratum, various covariance matrix structures were investigated, such as uniform (the 'standard' assumption), uniform with heterogeneous variance, and diagonal and unstructured covariance matrices, which were fitted using residual maximum likelihood. Models were compared using Akaike's information criterion, and it was found that the uniform error structure fitted the data best. As a consequence, the statistical analyses simplified to a split-plot ANOVA with animal as a random effect and diet, litter size and tissue as fixed effects. The effects of diet and litter size were tested against the residual error term from the animal stratum. The effect of tissue and its interaction with diet and litter size as well as the three-way interaction between tissue, diet and litter were all tested against the residual term from the withinanimal stratum.

To compare AA for bacteria, the data for all AA were combined and a similar approach was employed. The statistical analysis simplified to a split-plot ANOVA with animal as a random effect, and diet, litter size and AA as fixed effects. Post hoc $t$ tests were performed to compare mean values for tissues and AA and $P<0.05$ was declared statistically significant.

All data were analysed in Genstat 10, release 10.1 (VSN International Ltd, Hemel Hempstead, Herts, UK).

\section{Results}

All animals remained in good health throughout the experimental period except one NAB animal (LS9) that was not able to adapt to the experimental diet and was removed from the study. Where no interaction was detected between litter size and antibiotic supplied, only main effects are presented in the tables.

\section{Performance of lactating does}

As lactation progressed, milk production increased $(P<0.001)$ together with body-weight loss $(P=0 \cdot 011)$. Does gained weight in L1 $(16.2 \mathrm{~g} / \mathrm{d})$, and started to lose weight in L2 $(-5 \cdot 2 \mathrm{~g} / \mathrm{d})$, but significant losses $(-11.7 \mathrm{~g} / \mathrm{d})$ were detected during L3. No significant changes in food consumption were observed through lactation (Table 1).

Litter size, induced by cross-fostering, impacted on milk yield $(P=0.006)$, but neither feed intake nor body weight was affected. No antibiotic effect was detected either on DM intake, body-weight change or milk yield.

\section{Caecal parameters and amino acid concentration in bacteria, liver and milk}

In lactating does, the caecal weight (282.2 (SE 6.99) g) represented $7 \%$ of body weight and the $\mathrm{pH}$ of the caecal contents averaged $6 \cdot 45$. Neither was affected by experimental treatment. Total VFA concentration was $46 \cdot 2 \mathrm{~mm}$, with acetic acid the most abundant VFA (C2; 71.6\%) followed by butyric (C4; $20.8 \%)$ and propionic (C3, 7.5\%) acids. Although apparently total VFA concentration was lower with the antibiotic (61.5 v. $33.2 \mathrm{~mm}$ for $\mathrm{NAB}$ and $\mathrm{BAC}$ animals respectively),

Table 1. Effect of experimental diet (no antibiotic diet (NAB), bacitracin diet (BAC) or control diet), litter size and period of lactation on feed intake, body-weight changes and milk yield in lactating does

(Mean values and standard errors of difference)

\begin{tabular}{|c|c|c|c|c|c|c|c|c|c|c|}
\hline \multirow[b]{2}{*}{ Diet } & \multirow[b]{2}{*}{ Litter size } & \multicolumn{3}{|c|}{ Daily feed intake (g) } & \multicolumn{3}{|c|}{ Body-weight changes $(\mathrm{g} / \mathrm{d})$} & \multicolumn{3}{|c|}{ Milk yield $(\mathrm{g} / \mathrm{d})$} \\
\hline & & L1 & L2 & L3 & L1 & L2 & L3 & L1 & L2 & L3 \\
\hline NAB & LS9 & 370 & 338 & 289 & $22 \cdot 7$ & $-13 \cdot 4$ & $-15 \cdot 5$ & 176 & 203 & 216 \\
\hline NAB & LS5 & 322 & 284 & 293 & $13 \cdot 2$ & -9.7 & -5.5 & 135 & 149 & 197 \\
\hline BAC & LS9 & 313 & 330 & 319 & $28 \cdot 0$ & -2.6 & $-14 \cdot 7$ & 138 & 178 & 213 \\
\hline BAC & LS5 & 309 & 320 & 281 & $14 \cdot 7$ & $7 \cdot 3$ & $-20 \cdot 1$ & 128 & 146 & 172 \\
\hline Control & LS9 & 353 & 314 & 298 & $18 \cdot 5$ & -11.9 & -13.5 & 173 & 195 & 209 \\
\hline Control & LS5 & 322 & 267 & 322 & $2 \cdot 3$ & -0.6 & $-1 \cdot 2$ & 136 & 142 & 194 \\
\hline SED & & $36 \cdot 2$ & $42 \cdot 3$ & 39.9 & $20 \cdot 44$ & $7 \cdot 96$ & $18 \cdot 57$ & 25.9 & $24 \cdot 6$ & 39.5 \\
\hline \multicolumn{11}{|c|}{ Statistical significance* } \\
\hline Period & & & & 0.087 & & & 0.014 & & & $<0.001$ \\
\hline Diet & & & & 0.917 & & & 0.083 & & & 0.498 \\
\hline Litter size & & & & 0.166 & & & 0.128 & & & 0.006 \\
\hline
\end{tabular}

LS9, litter size of nine pups; LS5, litter size of five pups; L1, days 1 to 8 of lactation; L2, days 9 to 17 of lactation; L3, days 18 to 25 of lactation.

${ }^{*}$ Data were analysed by residual maximum likelihood (REML), assuming uniform correlation with heterogeneous variance for the three time periods. The two- and three-way interactions were non-significant $(P>0.10)$. 
no significant differences were observed (Table 2), and VFA proportions were also unaltered.

Total analysed AA concentration (mg/g DM; Table 3) was highest in liver (557 (SE 32.8)), followed by bacteria (468.4 (SE 11.9)) and diet (140 (SE 6.6)), of which lysine represented $7.03,6.49$ and $4.83 \%$, respectively.

\section{${ }^{15} \mathrm{~N}$ enrichment in caecal ammonia and urine urea}

In the NAB group, average ${ }^{15} \mathrm{~N}$ abundance in urine urea $(0.87$ (SE 0.015$)$ atom \%) was greater $(P<0.05)$ than in microbial-N (0.61 (SE 0.076) atom \%), and the latter was similar to the caecal ammonia enrichment (0.63 atom \%). Assuming that urine and plasma urea have the same ${ }^{15} \mathrm{~N}$ enrichment and based on a natural abundance of 0.366 atom $\%^{(14)}$, the maximum contribution of plasma urea-N to caecum bacterial-N was $0.48((0.610-0.366) /(0.870-0.366))$, with the remainder derived from dietary sources. If, however, caecal ammonia were the precursor then, by similar reasoning, this would account for $>0.90$ of microbial-N, with only a small contribution required from feed residue in the large intestine. The ammonia option is probably closer to the real situation.

\section{${ }^{15} \mathrm{~N}$ enrichment in amino acids}

No effects of diet or litter size were detected on $\left[{ }^{15} \mathrm{~N}\right]$ amino acid enrichment and therefore mean ${ }^{15} \mathrm{~N}$ enrichment values for each of the thirteen AA monitored in bacteria, liver and milk are presented in Table 4. Differences in lysine enrichment between the various treatments (litter size and NAB $v$. BAC) were small (2\% for bacteria, $6 \%$ for liver and $5 \%$ for milk, respectively). Enrichments (atom \% excess; ape) in threonine were more variable but the numerical differences between diet ( 0.069 for NAB and 0.077 for BAC) and litter size (0.071 for LS5 and 0.075 for LS9) were not statistically significant. The ${ }^{15} \mathrm{~N}$ enrichments differed $(P<0.05)$ between individual AA, both between bacteria, liver and milk and within bacteria. In the microbial protein, threonine had the greatest enrichment $(0.31$ ape). Most of the other AA had similar enrichments (from 0.279 to 0.231 ape) in the order tyrosine, glutamate, isoleucine, aspartate, valine, leucine, phenylalanine serine and lysine and these were all higher $(P<0.04)$ than proline and glycine $(0.068$ and 0.197 ape, respectively). All AA showed a greater enrichment in microbes than in either milk or liver $(P<0 \cdot 001)$. With the exception of phenylalanine $(P=0.96)$, enrichments were greater in milk than in liver $(P<0.001$ for most amino acids except for proline $P=0 \cdot 017$, tyrosine $P=0 \cdot 020$, and threonine $P=0.035)$.

\section{Caecotrophy contribution}

Microbial lysine contribution to tissue lysine was estimated using both liver and milk lysine enrichments, but was greater based on milk (23.1 v. $18.7 \%$; $P<0 \cdot 05)$. With milk, microbial lysine absorption was 0.45 (SE 0.014) $\mathrm{g} / \mathrm{d}$ from an estimated total intake of bacteria of 15.5 (SE 0.91$) \mathrm{g} \mathrm{DM} / \mathrm{d}$. There was no effect of antibiotic treatment or litter size on either microbial or diet contribution to tissues, nor was microbial lysine absorption altered (Table 5).

\section{Discussion \\ $\left[{ }^{15}\right.$ N]lysine approach}

Caecotrophy is a crucial mechanism to enhance protein supply in rabbits. This process has been quantified for growing rabbits ${ }^{(3,5)}$, but few studies have investigated the contribution in lactating does ${ }^{(7)}$. Furthermore, conventional methodology, based on a wooden collar, is unsuitable for lactating does. In the present study, an alternative non-invasive methodology, based on incorporation of inorganic ${ }^{15} \mathrm{~N}$ into microbial lysine and validated already against the conventional procedure in growing rabbits ${ }^{(3)}$, has been employed.

Microbial lysine used for body protein synthesis can arise either from direct absorption from the small intestine, as occurs in pigs ${ }^{(1)}$, or from caecotrophy. In a previous study with collared growing rabbits, Belenguer et al. ${ }^{(3)}$ estimated that $<3 \%$ of microbial lysine was incorporated from direct gut absorption and a similar value is assumed for the present study.

In growing animals the microbial contribution was estimated using liver protein because this has a high rate of protein turnover and ${ }^{15} \mathrm{~N}$ enrichment may reach plateau in a shorter time ${ }^{(3)}$. Nevertheless, certain hepatic proteins, such as those involved in cell structure, may have low rates of

Table 2. Effect of experimental diet (no antibiotic diet (NAB), bacitracin diet (BAC) or control diet) and litter size on caecum weight, pH and volatile fatty acid (VFA) concentrations and proportions of acetic, propionic and butyric acids in lactating does

(Mean values and standard errors of difference)

\begin{tabular}{|c|c|c|c|c|c|c|c|}
\hline Diet & Litter size & Weight (g) & $\mathrm{pH}$ & Total VFA (mM) & Acetic acid (\%) & Propionic acid (\%) & Butyric acid (\%) \\
\hline \multirow[t]{2}{*}{ NAB } & LS9 & 279 & 6.09 & $69 \cdot 3$ & $68 \cdot 3$ & $6 \cdot 9$ & $24 \cdot 5$ \\
\hline & LS5 & 264 & $6 \cdot 48$ & $53 \cdot 8$ & $74 \cdot 8$ & $6 \cdot 7$ & $18 \cdot 5$ \\
\hline \multirow[t]{2}{*}{ BAC } & LS9 & 300 & $6 \cdot 61$ & 34.5 & 71.5 & $7 \cdot 2$ & $21 \cdot 3$ \\
\hline & LS5 & 289 & $6 \cdot 73$ & $32 \cdot 0$ & 69.9 & $9 \cdot 2$ & $20 \cdot 9$ \\
\hline \multirow[t]{2}{*}{ Control } & LS9 & 289 & 6.49 & $45 \cdot 7$ & 74.4 & $6 \cdot 8$ & $18 \cdot 8$ \\
\hline & LS5 & 272 & $6 \cdot 30$ & $41 \cdot 7$ & $70 \cdot 7$ & $8 \cdot 2$ & $21 \cdot 1$ \\
\hline SED & & $25 \cdot 6$ & 0.270 & 18.55 & $3 \cdot 61$ & 1.66 & $3 \cdot 24$ \\
\hline \multicolumn{8}{|c|}{ Statistical significance ${ }^{*}$} \\
\hline Diet & & 0.46 & 0.15 & 0.12 & 0.78 & 0.52 & 0.78 \\
\hline LS & & 0.35 & 0.49 & 0.50 & 0.86 & 0.27 & 0.47 \\
\hline
\end{tabular}

LS9, litter size of nine pups; LS5, litter size of five pups.

${ }^{\star}$ Data were analysed by two-way ANOVA. The interaction between diet and litter size was not significant $(P>0 \cdot 10)$. 
Table 3. Amino acid composition (mg/g DM) of caecal bacteria, liver and diet

(Mean values with their standard errors)

\begin{tabular}{|c|c|c|c|c|c|c|}
\hline & \multicolumn{2}{|c|}{ Bacteria (n 16) } & \multicolumn{2}{|c|}{ Liver ( $n$ 4) } & \multicolumn{2}{|c|}{ Diet $(n 2)$} \\
\hline & Mean & SE & Mean & SE & Mean & SE \\
\hline \multicolumn{7}{|l|}{ Non-essential } \\
\hline Alanine & $37 \cdot 1$ & 0.85 & $34 \cdot 8$ & 0.70 & $6 \cdot 4$ & 0.06 \\
\hline Glycine & $25 \cdot 7$ & 0.58 & 33.7 & 1.52 & $7 \cdot 0$ & 0.21 \\
\hline Proline & $26 \cdot 0$ & 0.85 & $35 \cdot 0$ & 1.0 & $10 \cdot 8$ & $1 \cdot 11$ \\
\hline Serine & 23.8 & 0.40 & 31.4 & 1.01 & $7 \cdot 7$ & 0.15 \\
\hline Aspartate & $59 \cdot 0$ & 0.99 & $49 \cdot 6$ & 0.83 & $18 \cdot 7$ & 1.91 \\
\hline Glutamate & $66 \cdot 4$ & $1 \cdot 26$ & $82 \cdot 8$ & 2.58 & $26 \cdot 0$ & 0.56 \\
\hline Tyrosine & $25 \cdot 4$ & 0.70 & $21 \cdot 9$ & 0.87 & $7 \cdot 3$ & 0.73 \\
\hline \multicolumn{7}{|l|}{ Essential } \\
\hline Lysine & $30 \cdot 4$ & 1.17 & $39 \cdot 2$ & $5 \cdot 47$ & $6 \cdot 8$ & 0.30 \\
\hline Valine & $33 \cdot 3$ & 1.08 & $35 \cdot 7$ & $3 \cdot 24$ & $8 \cdot 2$ & 0.69 \\
\hline Leucine & $31 \cdot 3$ & 0.94 & 47.5 & $5 \cdot 61$ & $8 \cdot 8$ & 0.03 \\
\hline Isoleucine & $23 \cdot 1$ & 0.79 & $20 \cdot 7$ & 2.09 & $5 \cdot 4$ & 0.24 \\
\hline Threonine & 30.9 & 0.72 & $30 \cdot 2$ & 0.60 & $6 \cdot 0$ & 0.21 \\
\hline Phenylalanine & $19 \cdot 8$ & 0.60 & $27 \cdot 0$ & 3.69 & $6 \cdot 6$ & 0.26 \\
\hline Arginine & 23.7 & 0.65 & 39.8 & 2.62 & $10 \cdot 1$ & 0.13 \\
\hline Histidine & $12 \cdot 4$ & 0.30 & $27 \cdot 7$ & 0.96 & $5 \cdot 0$ & 0.02 \\
\hline $\begin{array}{l}\text { Sum of amino } \\
\text { acids }\end{array}$ & $468 \cdot 4$ & $11 \cdot 86$ & $557 \cdot 3$ & $32 \cdot 80$ & $140 \cdot 6$ & 6.59 \\
\hline
\end{tabular}

turnover and not attain isotopic plateaux even within $30 \mathrm{~d}$ and thus lead to an underestimate of microbial protein contribution $^{(15)}$. Such problems are less for export proteins, such as hepatic albumin and milk casein, and the latter provides a readily accessible, non-invasive source in lactating animals. Furthermore, studies in the dairy goat have shown that constant enrichments in casein are achieved within $30 \mathrm{~h}$ of the precursor pool reaching a plateau ${ }^{(16)}$. The higher

Table 4. Mean ${ }^{15} \mathrm{~N}$ enrichment (atom \% excess) in amino acids in caecal bacteria, liver and milk of lactating does fed on a $\left({ }^{15} \mathrm{NH}_{4}\right)_{2} \mathrm{SO}_{4}$-supplemented diet

(Mean values and standard errors of difference)

\begin{tabular}{lccccc}
\hline Amino acids* & Bacteria & Liver & Milk & SED & $\begin{array}{c}\text { Effect of } \\
\text { tissue }(P) \dagger\end{array}$ \\
\hline Non-essential & & & & & \\
$\quad$ Alanine & 0.245 & 0.213 & 0.119 & 0.0044 & $<0.001$ \\
$\quad$ Glycine & 0.197 & 0.154 & 0.099 & 0.0045 & $<0.001$ \\
Proline & 0.068 & 0.040 & 0.046 & 0.0027 & $<0.001$ \\
Serine & 0.233 & 0.166 & 0.119 & 0.0059 & $<0.001$ \\
Aspartate & 0.273 & 0.183 & 0.087 & 0.0028 & $<0.001$ \\
Glutamate & 0.279 & 0.182 & 0.125 & 0.0043 & $<0.001$ \\
$\quad$ Tyrosine & 0.279 & 0.072 & 0.077 & 0.0027 & $<0.001$ \\
Essential & & & & & \\
$\quad$ Lysine & 0.231 & 0.043 & 0.053 & 0.0032 & $<0.001$ \\
$\quad$ Valine & 0.261 & 0.062 & 0.082 & 0.0032 & $<0.001$ \\
$\quad$ Leucine & 0.258 & 0.053 & 0.077 & 0.0025 & $<0.001$ \\
$\quad$ Isoleucine & 0.274 & 0.070 & 0.105 & 0.0048 & $<0.001$ \\
$\quad$ Threonine & 0.312 & 0.036 & 0.044 & 0.0092 & $<0.001$ \\
$\quad$ Phenylalanine & 0.253 & 0.047 & 0.047 & 0.0022 & $<0.001$ \\
\hline
\end{tabular}

* Individual amino acid enrichments were log-transformed and analysed by ANOVA, and SED have been back-transformed to the original units. Animal was regarded as a random effect and diet, litter size, tissue and their interactions as fixed effects. SED is based on the residual mean sum of squares from the within-animal stratum. The main effects of diet and litter size as well as all two- and three-way interactions were non-significant $(P>0.05)$.

†Post hoc $t$ tests were performed to compare tissues. All comparisons gave $P<0.001$, except for liver $v$. milk, which gave $P=0.017, P=0.020, P=0.96$ and $P=0.035$ for proline, tyrosine, phenylalanine and threonine, respectively. protein-bound lysine enrichment in milk protein provides a better representation of the amount of lysine (and other AA) of microbial origin available to the tissues of the animal.

\section{Enrichment of amino acid-nitrogen in bacteria and tissues}

There are various sources of $\mathrm{N}$ for microbes in the caecum, and differences in amino acid enrichments in microbial protein reflect differential inflows from labelled ammonia, body proteins and undigested dietary residues. The contributions of these various $\mathrm{N}$ sources vary between AA, as already demonstrated for ruminants ${ }^{(17,18)}$. The AA enrichment patterns in caecal bacteria of the lactating does are not dissimilar to previous values reported in fattening rabbits ${ }^{(3)}$. In general, the high enrichment of glutamate and aspartate would confirm the central role played by glutamate as an intermediate in $\mathrm{N}$ transfer between $\mathrm{AA}^{(17)}$. The lowest enrichments corresponded to glycine and proline and such values agree with previous observations in ruminants ${ }^{(17,19)}$. These low enrichments are unlikely to be due to high rates of intestinal supply of unlabelled proline but it is known that L-proline is a strong allosteric inhibitor of proline synthesis (through glutamate quinase). Therefore, moderate supply of preformed proline, either from undigested dietary protein or tissue sources, may limit synthesis de novo and indeed Atasoglu et $a{ }^{(19)}$ indicated that microbial biosynthesis of proline is markedly reduced if proline is supplied directly.

Tissue AA enrichment depends on the amounts and enrichments of the two 'exogenous' sources, bacteria and food, plus metabolism within the animal. For AA that undergo extensive transamination, for example, glutamate, aspartate and alanine of non-essential AA and valine, leucine and isoleucine of the essential AA, such actions will obscure the contribution of bacterial amino acid-carbon to tissue protein. A better index is given by essential AA that do not undergo transamination, such as lysine and threonine. Threonine was the most enriched AA in bacterial extracts, but had the lowest contribution from microbial sources. Relative to lysine, the ratio tissue:bacterial ${ }^{15} \mathrm{~N}$ enrichment in threonine was 2 -fold lower. Threonine is an important component of mucins, and a direct utilisation of substantial quantity of enteral sources (including recycled bacterial protein) by gut tissue for mucin synthesis may limit the amount available for peripheral tissues ${ }^{(20,21)}$ and would delay the equilibrium in threonine enrichment within plasma and tissues.

\section{Microbial contribution to amino acid requirements}

The aim of the present experiment was to study the contribution of microbes to amino acid requirements during lactation and how this is affected by different levels of intake, induced by altering the litter size, and the inclusion of dietary bacitracin. The addition of bacitracin in the diet, however, did not affect microbial contribution, and that fits with recent observations that this antibiotic does not alter bacterial biodiversity in lactating rabbits ${ }^{(22)}$.

In growing rabbits, caecotrophy can contribute up to 0.38 of total protein intake ${ }^{(23)}$. Higher values may be observed with adults at maintenance or on a protein-free $\operatorname{diet}^{(2)}$. The heaviest protein demand, however, arises during lactation. During late lactation the microbial contribution to tissue lysine was 
Table 5. Effect of experimental diet (no antibiotic diet (NAB) or bacitracin diet (BAC)) and litter size on dietary and microbial contribution through caecotrophy $\left(\mathrm{M}_{\text {lys }}(\mathrm{Cec})\right)$ to milk lysine, absorption of dietary $\left(\mathrm{D}_{\text {LysA }}\right)$ and microbial lysine through caecotrophy ( $\left.\mathrm{M}_{\mathrm{Lys}}\right)$ and microbial intake in lactating does fed on a $\left({ }^{15} \mathrm{NH}_{4}\right)_{2} \mathrm{SO}_{4}$-supplemented diet

(Mean values and standard errors of difference)

\begin{tabular}{|c|c|c|c|c|c|c|}
\hline \multirow[b]{2}{*}{ Diet } & \multirow[b]{2}{*}{ Litter size } & \multicolumn{2}{|c|}{ Contribution to tissue lysine } & \multicolumn{2}{|c|}{ Lysine absorption (g/d) } & \multirow[b]{2}{*}{ Microbial intake (g DM/d) } \\
\hline & & Diet & $\mathrm{M}_{\text {lys }}(\mathrm{Cec})$ & $D_{\text {LysA }}$ & $M_{\text {LysA }}$ & \\
\hline \multirow[t]{2}{*}{ NAB } & LS5 & 0.765 & 0.225 & 1.48 & 0.45 & $15 \cdot 9$ \\
\hline & LS9 & 0.773 & 0.217 & 1.65 & $0 \cdot 48$ & $13 \cdot 8$ \\
\hline \multirow[t]{2}{*}{ BAC } & LS5 & 0.752 & 0.238 & $1 \cdot 35$ & 0.44 & $16 \cdot 8$ \\
\hline & LS9 & 0.747 & 0.243 & $1 \cdot 33$ & 0.45 & $15 \cdot 4$ \\
\hline SED & & 0.0158 & 0.0158 & 0.116 & 0.041 & $2 \cdot 66$ \\
\hline \multicolumn{7}{|c|}{ Statistical significance ${ }^{*}$} \\
\hline Diet & & 0.12 & $0 \cdot 12$ & 0.02 & 0.53 & 0.53 \\
\hline Litter size & & 0.88 & 0.88 & 0.42 & 0.60 & 0.40 \\
\hline
\end{tabular}

LS5, litter size of five pups; LS9, litter size of nine pups.

* Data were analysed by two-way ANOVA. The interaction was not significant $(P>0 \cdot 10)$.

0.23 (SE 0.035) based on milk protein, similar to liverderived values in lactating does $(0.18 \text { (SE 0.048) })^{(24)}$ using ion-exchange chromatography and growing rabbits $(0.23$ $($ SE $0 \cdot 057))^{(3)}$ fed different sources of carbohydrate. The voluntary intake of lactating females is $30 \%$ greater than in growing rabbits ${ }^{(25)}$ and 3 -fold higher than for adult animals ${ }^{(26)}$. Such differences would impact on the caecal environment and microbial yield. Furthermore, during lactation the requirements of the does are not usually met fully by food intake and they lose weight ${ }^{(27)}$. This may be partially offset by increased use of caecotrophic sources. Indeed, microbial lysine absorption was four times greater in these lactating does $(0.5 \mathrm{~g} / \mathrm{d})$ than for growing rabbits $(0 \cdot 12 \mathrm{~g} / \mathrm{d})^{(3)}$. This represents more than $25 \%$ of the apparent digestible lysine requirement of lactating does $(1.8 \mathrm{~g} / \mathrm{d}$, assuming a mean value of $300 \mathrm{~g} \mathrm{DM}$ intake/ $\left.\mathrm{d}^{(28)}\right)$.

Therefore, although intake of soft faeces during lactation was much greater than observed in growing rabbits, the relative contribution of caecotrophes to total $\mathrm{N}$ supply was similar because the lactating animals ate proportionally more. As with ruminants, amino acid requirements of the rabbit are met by both dietary and microbial protein but one advantage of ingestion of microbial protein (or caecotrophes) is the higher content of the limiting AA, lysine, methionine and histidine compared with plant protein ${ }^{(29)}$. AA requirements for lactating does remain to be established ${ }^{(30)}$ but the high concentration of lysine and methionine in both the whole body and milk (383 and 77 v. 451 and $150 \mathrm{mg} / \mathrm{g} \mathrm{N}$, for lysine and methionine, respectively ${ }^{(30)}$ ) confirms why it is important for the doe to improve microbial protein intake. Comparison of these data with those in growing rabbits ${ }^{(3)}$ might suggest, however, that caecotrophes ingestion or production may have limits. If this is the case, then is caecotrophy restricted by a physical limitation of ingestion or because of an unbalanced nutrient supply? Although four-fold more caecal-derived lysine was ingested during lactation than growth this was still not enough to support both milk production and maintain the nutritional requirements of the mother, as these lose weight. Partly this was due to intake either being maintained or even reduced as lactation progressed but while milk output increased. During this period, demands for both protein and energy are increased but the doe has to balance intake of the diet, with higher energy but lower protein quality, against caecal material that offers good-quality protein but relatively little energy. Such a balance may not be fixed, however, and supply of a better-quality (or more energy-dense) diet may alter the amount of recycled bacterial protein and permit the mother to maintain both her lean and adipose tissue stores. This hypothesis needs to be tested.

The microbial lysine incorporation method is non-invasive and probably the most suitable to estimate microbial protein intake in lactating does because it does not alter animal metabolism or behaviour. Despite the importance of the caecotrophy process to doe nutrition, $\mathrm{N}$ recycling was affected neither by ingestion of antimicrobial substances that inhibit microbial yield nor through changing nutrient demand by manipulating litter size. Why the caecotrophic response remains constant even with these altered demands and pressures has yet to be answered.

\section{Acknowledgements}

There were no conflicts of interest among authors of the present study. Work was financed by the Dirección General de Aragón (DGA), through the Research Project reference PM 095/2006. L. A. was funded by a doctoral fellowship (Programa de Formación de Investigadores del Departamento de Educación, Universidades e Investigación del Gobierno Vasco) and by a Marie Curie Training site award (HPMTCT-2001-00409) during her stage at the Rowett Research Institute. Part of the present study was funded by core grants to the Rowett Research Institute, and Biomathematics and Statistics Scotland (BioSS) by the Scottish Executive. L. A. and A. B. were in charge of the farm and laboratory work in Spain under J. B. and M. F's. supervision; G. L. supervised L. A.'s training stage in the Rowett Research Institute and contributed with J. B. and M. F. in the writing of the paper. G. H. performed the statistical analyses of results.

\section{References}

1. Torrallardona D, Harris CI \& Fuller MF (2003) Pigs' gastrointestinal digesta provide them with essential amino acids. $J$ Nutr 133, 1127-1131.

2. Cheeke PR (1987) Rabbit Feeding and Nutrition. Corvallis, OR: Academic Press, Inc. 
3. Belenguer A, Balcells J, Guada JA, Decoux M \& Milne E (2005) Protein recycling in growing rabbits: contribution of microbial lysine to amino acid metabolism. Br J Nutr 94, 763-770.

4. Fraga MJ, Perez de Ayala P, Carabaño R \& de Blas JC (1991) Effect of type of fiber on the rate of passage and on the contribution of soft feces to nutrient intake of finishing rabbits. J Anim Sci 69, 1566-1574.

5. Carabaño R, de Blas JC \& García AI (2000) Recent advances in nitrogen nutrition in rabbits. World Rabbit Sci 8, Suppl. 1, $15-28$.

6. Belenguer A, Balcells J, Fondevila M \& Torre C (2002) Caecotrophes intake in growing rabbits estimated either from urinary excretion of purine derivatives or from direct measurement using animals provided with a neck collar: effect of type and level of dietary carbohydrate. Anim Sci 74, 135-144.

7. Lorente M, Fraga MJ, Carabaño R \& de Blas JC (1988) Coprophagy in lactating does fed different diets. J Appl Rabbit Res 11, $11-15$.

8. Van Soest PJ, Robertson JB \& Lewis RA (1991) Methods for dietary fiber, neutral detergent fiber and non starch polysacharides in relation to animal nutrition. J Dairy Sci 74, 3583-3597.

9. Jouany JP (1982) Volatile fatty acid and alcohol determination in digestive contents, silage juices, bacterial cultures and anaerobic fermentor contents. Sci Aliments 2, 131-144.

10. Cohen SA, Meys M \& Tarvin TL (1989) The Pico-Tag Method. A Manual of Advanced Techniques for Amino Acids Analysis. Bedford, MA: Millipore Corporation.

11. Sarraseca A, Milne E, Metcalf MJ \& Lobley GE (1998) Urea recycling in sheep: effects of intake. Br J Nutr 79, 79-88.

12. Jensen ES (1991) Evaluation of automated analysis of ${ }^{15} \mathrm{~N}$ and total $\mathrm{N}$ in plant material and soil. Plant Soil 133, 83-92.

13. Storm E, Brown DS \& Orskov ER (1983) The nutritive value of rumen micro-organisms in ruminants. 3. The digestion of microbial amino and nucleic acids in, and losses of endogenous nitrogen from the small intestine of sheep. Br J Nutr 50, 479-485.

14. Buresh RJ, Austin ER \& Crawell ET (1982) Analytical methods in ${ }^{15} \mathrm{~N}$ research. Fertil Res 3, 37-62.

15. Connell A, Calder AG, Anderson SE \& Lobley GE (1997) Hepatic protein synthesis in the sheep: effect of intake as monitored by use of stable-isotope-labelled glycine, leucine and phenylalanine. Br J Nutr 77, 255-271.

16. Bequette BJ, Backwell FR \& Crompton LA (1998) Current concepts of amino acid and protein metabolism in the mammary gland of the lactating ruminant. J Dairy Sci 81, 2540-2559.

17. Salter DN, Daneshvar K \& Smith RH (1979) The origin of nitrogen incorporated into compounds in the rumen bacteria of steers given protein- and urea-containing diets. Br J Nutr 41, 197-209.
18. Atasoglu C, Guliye AY \& Wallace RJ (2004) Use of stable isotopes to measure de novo synthesis and turnover of amino acid-C and $-\mathrm{N}$ in mixed micro-organisms from the sheep rumen in vitro. Br J Nutr 91, 253-262.

19. Atasoglu C, Valdes C, Newbold CJ \& Wallace RJ (1999) Influence of peptides and amino acids on fermentation rate and de novo synthesis of amino acids by mixed micro-organisms from the sheep rumen. Br J Nutr 81, 307-314.

20. Goudoever JB, Stoll B, Henry JF, Burrin DG \& Reeds PJ (2000) Adaptive regulation of intestinal lysine metabolism. Proc Nat Acad Sci U S A 97, 11620-11625.

21. Schaart MW, Schierbeek H, van der Schoor SRD, Stoll B, Burrin DG, Reeds PJ \& van Goudoever JB (2005) Threonine utilization is high in the intestine of piglets. J Nutr 135, $765-770$.

22. Abecia L, Fondevila M, Balcells J, Lobley GE \& McEwan NR (2007) The effect of medicated diets and level of feeding on caecal microbiota of lactating rabbit does. J Appl Microbiol 103, 787-793.

23. Hörnicke H \& Björnhag G (1980) Coprophagy and related strategies for digesta utilization. In Digestive Physiology and Metabolism in Ruminants, pp. 707-730 [Y Ruckebusch and P Thivend, editors]. Lancaster, UK: MTP Press.

24. Belenguer A (2004) Absorción de nitrógeno microbiano en conejos en crecimiento y hembras en lactación en relación con las variaciones en el tipo de hidrato de carbono suministrado en la ración (Microbial nitrogen absorption in growing rabbits and lactating does fed diets formulated with different source of carbohydrate). PhD Thesis, University of Zaragoza.

25. Parigi Bini R \& Xiccato G (1998) Energy metabolism and requirement. In The Nutrition of the Rabbit, pp. 103-131 [C de Blas and J Wiseman, editors]. Wallingford: CABI Publishing.

26. Fraga MJ, Lorente M, Carabaño R \& de Blas JC (1989) Effect of diet and of remating interval on milk production and milk composition of the doe rabbit. Anim Prod 48, 459-466.

27. Xiccato G (1996) Nutrition of lactating does. In 6th World Rabbit Congress, Toulouse, vol. 1, pp. 29-47. Toulouse, France: F Lebas.

28. de Blas C \& Mateos GG (1998) Feed formulation. In The Nutrition of the Rabbit, pp. 241-253 [C de Blas and J Wiseman, editors]. Wallingford: CABI Publishing.

29. Wallace RJ (1994) Amino acid and protein synthesis, turnover and breakdown by ruminal microorganisms. In Principles of Protein Nutrition of Ruminants, pp. 71-112 [JM Asplund, editor]. Boca Raton, FL: CRC Press.

30. Fraga MJ (1998) Protein requirements. In The Nutrition of the Rabbit, pp. 133-143 [C de Blas and J Wiseman, editors]. Wallingford: CABI Publishing. 